\title{
Modelling of digesta passage rates in grazing and browsing domestic and wild ruminant herbivores
}

\author{
M. Moyo', E. B. Gueguim Kana ${ }^{2}$ \& I. V. Nsahlai ${ }^{1 \#}$ \\ ${ }^{1}$ Animal and Poultry Science, School of Agricultural, Earth and Environmental Sciences, University of KwaZulu-Natal, \\ P/Bag X01, Scottsville, Pietermaritzburg, South Africa, 3201. \\ ${ }^{2}$ Microbiology, School of Biochemistry, Genetics and Microbiology, University of KwaZulu-Natal, P/Bag X01, Scottsville, \\ Pietermaritzburg, Scottsville, South Africa, 3201.
}

(Received 19 October 2016; Accepted 28 March 2017; First published online 26 April 2017)

\author{
Copyright resides with the authors in terms of the Creative Commons Attribution 4.0 South African Licence. \\ See: http://creativecommons.org/licenses/by/4.0/za \\ Condition of use: The user may copy, distribute, transmit and adapt the work, but must recognise the authors and the South African \\ Journal of Animal Science.
}

\begin{abstract}
Ruminant utilization of poor-quality feeds is governed by rates of digestion and of passage through the rumen. The passage rate of feed material determines the quantity of bypass nutrients and the efficiency of synthesis of microbial protein in the rumen, making modelling of passage rate important. Artificial neural networks were used to develop models of liquid and solid passage rates. Studies that reported fractional passage rates, along with class and body mass of ruminants, were included in the dataset. Factors that affect rates of passage in all the studies were identified, which included animal and feed factors. The dataset was composed of observations of domestic and wild ruminants of variable body mass (1.5 to $1238 \mathrm{~kg}$ ) from 74 studies and 17 ruminant species from various climatic regions. Observations were randomly divided into two data subsets: $75 \%$ for training and $25 \%$ for validation. Developed models accounted for 66 and $82 \%$ of the variation in prediction of passage rates for solid and liquid, respectively. On validation with an independent dataset, these models attained 42 and $64 \%$ of precision in predicting passage rates for solid and liquid, respectively. Liquid and solid prediction passage rate models had no linear and mean bias in prediction. This study developed better prediction models for solid and liquid passage rates for ruminants fed on a variety of diets and/or feeds from different climatic regions.
\end{abstract}

Keywords: Artificial neural networks, intake, mean retention time, prediction equation, rumen

\# Corresponding author: nsahlaii@ukzn.ac.za

\section{Introduction}

Digesta in the rumen exists as liquid or solid, with the two phases intermingled. Fluid and solid passage rates through the rumen are important as they influence digestion of soluble food nutrients (Illius \& Gordon, 1991), the amount of short chain fatty acids absorbed in the rumen and those that pass out of the rumen (Lopez et al., 2003), the amount of bypass protein of dietary origin (Fox et al., 2004) and the amount of microbial protein available to the host as a protein source (Dijkstra et al., 2007). Studies have shown that outflow rates of particulate $\left(k_{p}\right)$ and liquid $\left(k_{l}\right)$ digesta from the rumen are influenced by many factors, some of which are tedious and impractical to study (Allen, 1996). A wide variety of factors influence passage rates, leading to differences in passage rate data collected among studies on the same or similar research topics (St-Pierre, 2007). In a large number of studies, there are treatment effects that have little influence on the passage rate variables being evaluated (Sauvant et al., 2008).

Attempts have been made to develop passage rate prediction equations based on feed chemistry (Nsahlai \& Apaloo, 2007), animal characteristics (Seo et al., 2006; Krizsan et al., 2010) and chewing time (Coleman et al., 2003) for various classes of ruminants. Illius \& Gordon (1991) predicted passage rate as a function of bodyweight, though its validity was questioned by Nsahlai \& Apaloo (2007). These studies yielded modest levels of precision in predictions. Evidence suggests that animals at different physiological stages fed on a wide range of diets differ in rates of passage of digesta (Nsahlai \& Apaloo, 2007). Prediction of passage rates using a combination of animal, environmental, and feed factors offers a more practical approach.

Artificial neural networks (ANN) are mathematical models that learn and generalize complex non-linear relationships between input and output data (Haykin, 1998). Given the non-linear nature of biological 
functions, ANN are suitable for modelling biological processes. In several ruminant studies, ANN have been used to model rumen fermentation patterns in dairy cows (Craninx et al., 2008), in vitro methane gas production (Dong \& Zhao, 2014), rumen fill (Adebayo, 2015), and growth patterns in sheep (Behzadi \& Aslaminejad, 2010; Ganesan et al., 2014). Little emphasis has been put on the use of mathematical modelling methods in ruminant digesta passage kinetics. Further, few studies, if any, have used ANN to model and describe biological processes of passage rates of digesta through the rumen and ultimately predict roughage intake. Modelling of passage rate would enable easy calculation of digesta passage rates, independent of the use of expensive rare earth elements as external markers. Passage rate prediction equations may find application in studies that seek to predict microbial protein synthesis, roughage intake and rumen fill. The objective of this study was therefore to develop robust liquid and solid passage rate prediction models for grazing and browsing ruminants using ANNs.

\section{Materials and methods}

Data were collected from studies that reported at least average values or ranges for bodyweights of the animals, and measured fractional passage rates and/or mean retention times in the reticulo-rumen. A dataset was created that contained passage rates from wild and domesticated ruminants. Factors that affect passage rates were identified in each of these studies. Qualitative factors that affect passage rates were coded with numerical weightings. These were (factor $=$ code/weighting): animal management (grazing $=1$ or indoors $=0$ ), feed class (silage $=1$ or non-silage $=0$ ), tannin content (feeds that were classified to be tannin rich were millet, sorghum, carob leaves, red clover and browse leaves $=1$ and all other feeds with minute tannin levels $=0$ ), and feeding regime (ad-libitum $=1$ or restricted $=0$ ). Physiological status (day of pregnancy and lactation), animal production level, amount of urea in the diet ( $/ \mathrm{kg} \mathrm{DM})$, animal body mass $(\mathrm{kg})$, and mature body mass $(\mathrm{kg})$ were also included.

Feed variables were chemical composition (dry matter (DM); neutral detergent fibre (NDF); acid detergent fibre (ADF); crude protein (CP), and ash contents, all in $\mathrm{g} / \mathrm{kg} \mathrm{DM}$ ), particle size (small = 1, medium $=2$, large $=3$, mixed sizes $=0$ ), and in-sacco degradability parameters (soluble fraction (a); slowly degradable fraction (b); rate of degradation (RD); potential degradability (PD) and $\mathrm{PD} \frac{1}{2}$ life: potential degradability at half-life ( $\mathrm{PD} \frac{1}{2}$ life:). Instead, the half-life of a solid matter in the rumen was calculated using rates of degradation (c) according to Grovum \& Phillips (1973), where: $\mathrm{t} \frac{1}{2}$ life $=(0.693 \div \mathrm{c})$. Degradation models used in computing DM loss from each study were identified. PD $\frac{1}{2}$ life was calculated using the following formulae: $\mathrm{PD} \frac{1}{2}$ life $=\mathrm{a}+\mathrm{b} \times\left[1-\exp \left(-\mathrm{c} \times \mathrm{t} \frac{1}{2}\right.\right.$ life) $]$ (no time lag model) or $\mathrm{PD} \frac{1}{2}$ life $=\mathrm{a}+\mathrm{b} \times[1-$ $\exp -\mathrm{c}\left(\mathrm{t} \frac{1}{2}\right.$ life $\left.\left.-\mathrm{L}\right)\right]$ (model accounting for time lag, where L: lag).

Dimensions of particles moving through the rumen were classified into three main groups according to their diameter: large $(>1 \mathrm{~mm})$, medium $(0.5-1 \mathrm{~mm})$, and small $(0.04-0.5 \mathrm{~mm})$. The degree of maturity, which is correlated with the physiological age (PA), was calculated with this formula: $\mathrm{PA}=$ (body mass $\div$ mature body mass). Ruminants were separated into three main feeding types according to the classification by Hofmann (1989) as a) grazers or roughage selectors (cattle, antelope-addax, buffalo, mouflon, muskoxen, nilgai, sheep and blackbuck =i); b) browsers or concentrate selectors (moose, okapi, roe deer, dik-dik, duikers and mouse deer = ii); and c) intermediate feeders (goats, anoa, reindeer, gazelle and ibex $=$ iii). Net energies for maintenance $\left(\mathrm{NE}_{\mathrm{m}}\right)$, fattening $\left(\mathrm{NE}_{\mathrm{f}}\right)$, lactation $\left(\mathrm{NE}_{\mathrm{l}}\right)$, conception $\left(\mathrm{N}_{\mathrm{c}}\right)$, and production $\left(\mathrm{NE}_{\mathrm{p}}\right)$ were calculated according to AFRC (1993). Since these formulae were developed for cattle, sheep and goats only, wild ruminant animals in the authors' database were categorized into either of the formulae for cattle, sheep, and goats using their bodyweight or mature size, and feeding habits. Animals were assigned to the formulae for 1) cattle (cattle, muskoxen, anoa, antelope-addax, buffaloes, moose, mouflon, nilgai, okapi, reindeer and roe deer); 2) sheep (sheep, blackbucks, and gazelles); and 3) goats (goats, dik-dik, duikers, mouse deer and ibex).

Few studies reported final bodyweight of animals at the end of the trial, which were used to compute $\mathrm{NE}_{\mathrm{f}}$. For studies that did not measure final bodyweight of experimental animals, it was assumed that all animals were at maintenance level throughout the trial. All values for net energy were computed in $\mathrm{MJ} / \mathrm{kg}$ per day. Days in milk reported as early and late lactation were taken to be 60 and 290 days, respectively, for cows. Three studies did not report the milk composition for sheep, ibex, and cows. Thus to calculate the energy value for milk, an average butter fat content for milk of sheep, ibex (Raynal-Ljutovac et al., 2008), and cows (Lock \& Garnsworthy, 2003) of 3.2, 3.5, and 3.8\%, respectively, was used. Milk content for ibex was assumed to be equivalent to that of goats. The sum of these NE values was used to calculate the total net energy requirements $\left(T N E_{R}\right)$. Animal production level $(A P L)$ was calculated $\left(A P L=T N E_{R} \div N E_{m}\right)$. 
For studies in which feed composition and degradation were not reported, but in which the types of feed or diet were reported, feed composition attributes and degradability parameters were looked up in journal articles. These included Hummel et al. (2006), Abdou (2016), Stanton \& LeValley (2014), Beefmagazine (2015), and Feedipedia (2016). Feeds and diets that did not have ADF or NDF had these compositional attributes calculated using a regression equation derived from the dataset. The equation for acid detergent fibre $(\mathrm{Y})$ and neutral detergent fibre $(\mathrm{X})(\mathrm{g} / \mathrm{kg} \mathrm{DM})$ was $\mathrm{Y}=36.04( \pm 11.420)+0.551( \pm$ $0.02086) X\left(n=360\right.$, Root Mean Square Error $\left.=61.55, R^{2}=0.66, \mathrm{CV}=18.9 \%\right)$

Where animals were fed a concentrate diet only, the ash content was taken to be $10 \%$. Passage rates reported as mean retention time in the rumen $\left(\mathrm{MRT}_{\mathrm{R}}\right.$ ) were converted to fractional passage rate (FPR) by taking the inverse of mean retention time: $F P R=1 \div M R T_{R}$. Mature body mass of each ruminant species was looked up from publications and databases. These included Frandsen (1992), Estes (1993), Jenkins et al. (1993), Schoeman (1996), Lewis et al. (2004; 2010), Wund \& Myers (2005), Cillie (2009), ADW (2014), Arkive (2016), and AWF (2016). Data from studies that failed to specify the animal species were eliminated. Most studies that reported solid passage rates did not measure fluid passage rates, and vice versa. Therefore, two datasets were collated for solid and liquid passage rates. Although publications that were collected to create these datasets might not include all published literature, studies used to build these datasets were readily available.

In the present work, two artificial neural network models were programmed on 32-bit Visual Basic version 6.0 to predict the liquid and solid passage rates. Each dataset was used separately. Observations from each dataset were separated randomly into two sub-subsets: $75 \%$ of the dataset for model development or training and $25 \%$ for model validation. Since different variables span wide ranges, normalization (within the interval $(-1,1)$ ) of input and output data was done. For modelling, a three-layer Levenberg-Marquardt BP neural network was adopted, which generally includes one input layer, one hidden layer and one output layer. Thus network topologies of 23-23-1 and 17-17-1 were adopted, corresponding to the numbers of neurons of input, hidden and output layers for solid passage and liquid passage rates, respectively, (Figure 1). Training was carried out using a back propagation algorithm. Both models were trained for 3200 and 3600 epochs at learning rate of 0.05 , and momentum of 0.8 and the net errors were reduced to 0.00018 and 0.00011 on validation data for solid passage and liquid passage rate, respectively.

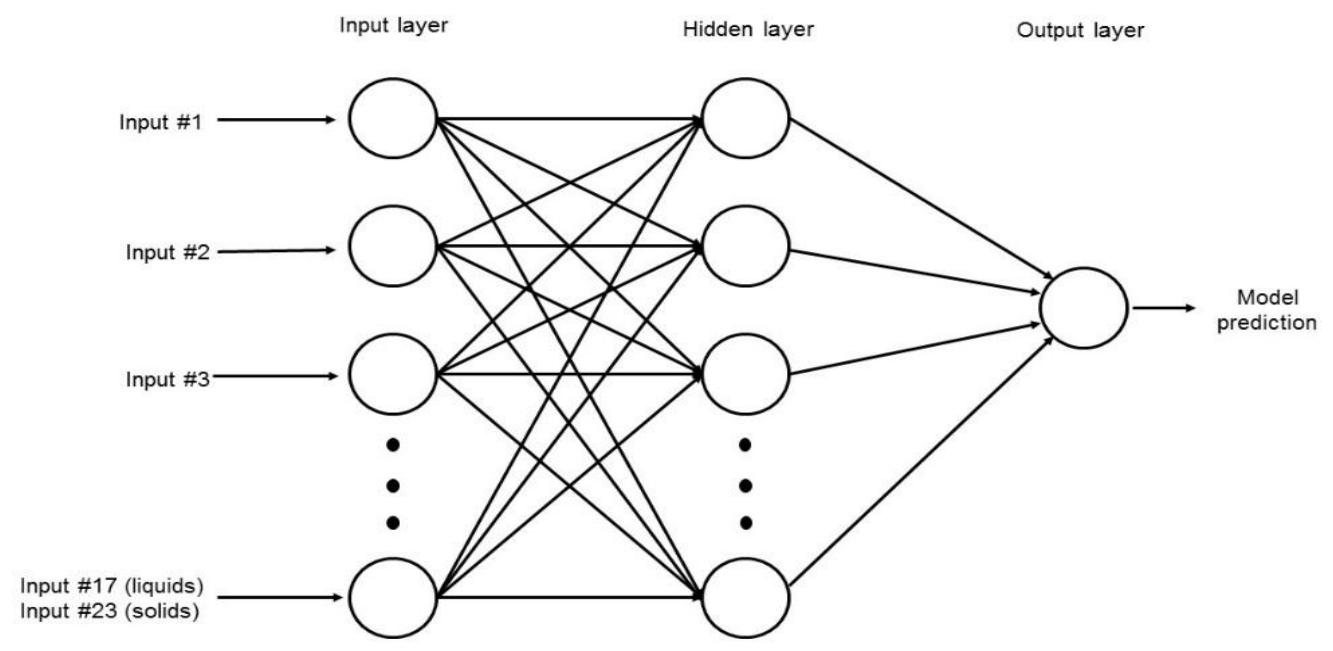

Figure 1 Basic structure of Levenberg-Marquardt back propagation neural network for modelling

The correlation procedure of SAS 9.3 software (SAS Institute Inc., Cary, NC, USA) was used to establish the Pearson correlation coefficients of any two input variables. For all evaluations, regression analyses of observed against predicted passage rates, residuals against observed passage rate and residuals against predicted passage rates were carried out using the linear regression procedure. Coefficients of determination were used to evaluate the precision of regression lines in approximating real data points of models. Root mean square error (RMSE) was used to determine the accuracy of these models. To evaluate the linear and mean biases in model predictions, the residuals (observed minus predicted passage rates) were regressed against predicted passage rates. The intercept and slopes of these 
regression lines were tested against 0 and 1, respectively, to determine any linear or mean bias (St-Pierre, 2003). Residual plots against observed passage rates were used to determine how close the predictions were to the real datasets. Process models developed in this study have been deposited in the Repository of Intelligent Models (REDIM, 2016) with accession numbers PRDA001762 and PRCN001814 for solid and liquid passage rate models respectively as indicated at http://www.redim.org.za/?search=PRDA001762 and http://www.redim.org.za/?search=PRCN001814.

\section{Results}

Numbers of observations in the datasets were unevenly distributed among the ruminant feeding types (67-78\% were grazers, 10-12\% were browsers, and 9-19\% were intermediate feeders). In predicting liquid passage rate, 12 observations were on pregnant and lactating animals (6 lactating and pregnant cattle, 3 lactating cattle, 2 lactating sheep and 1 pregnant sheep). Of 87 observations used for validation, seven (7) were on pregnant and lactating animals (2 lactating and pregnant cattle, 1 lactating cow and 4 pregnant sheep). All other classes of ruminants were neither lactating nor pregnant. For solid passage rates, 102 observations were on pregnant and lactating animals (7 pregnant cattle, 83 lactating cattle, 2 lactating sheep, 5 pregnant sheep and 5 lactating ibex). Thirty three (33) observations on pregnant and lactating animals ( 1 pregnant cow, 25 lactating cattle, 3 lactating ibex, 2 lactating sheep and 2 pregnant sheep) were used for validation. All other classes of ruminants were neither lactating nor pregnant. Tables 1 and 2 give the animal and diet compositional attributes used in model development, respectively.

Table 1 Species and feeding attributes of animals used in prediction and validation of passage rates

\begin{tabular}{|c|c|c|c|c|c|c|}
\hline \multirow{4}{*}{$\begin{array}{l}\text { No. of species } \\
\text { Mass }(\mathbf{k g})\end{array}$} & \multicolumn{3}{|c|}{ Liquid model } & \multicolumn{3}{|c|}{ Solid model } \\
\hline & \multirow{3}{*}{$\begin{array}{c}\text { Pred } \\
17 \\
1.5-890\end{array}$} & \multirow{3}{*}{$\begin{array}{c}\text { Valid } \\
12 \\
2.1-890\end{array}$} & \multirow{3}{*}{$\begin{array}{l}\text { Fractional } \\
\text { passage rate } \\
(\text { per h) }\end{array}$} & \multirow{3}{*}{$\begin{array}{c}\text { Pred } \\
15 \\
1.5-1238\end{array}$} & \multirow{3}{*}{$\begin{array}{c}\text { Valid } \\
11 \\
1.5-1238\end{array}$} & \multirow{3}{*}{$\begin{array}{c}\text { Fractional } \\
\text { passage rate (per } \\
\text { h) }\end{array}$} \\
\hline & & & & & & \\
\hline & & & & & & \\
\hline Grazers & 201 & 72 & & 300 & 103 & \\
\hline Cattle & 115 & 42 & $0.091 \pm 0.031$ & 202 & 62 & $0.031 \pm 0.020$ \\
\hline Sheep & 62 & 21 & $0.074 \pm 0.035$ & 92 & 35 & $0.035 \pm 0.015$ \\
\hline Buffaloes & 6 & 3 & $0.058 \pm 0.020$ & 2 & 0 & $0.024 \pm 0.0002$ \\
\hline Antelopes & 4 & 4 & $0.056 \pm 0.017$ & 5 & 3 & $0.024 \pm 0.004$ \\
\hline Mouflon & 1 & 0 & 0.026 & 0 & 0 & - \\
\hline Muskoxen & 11 & 2 & $0.050 \pm 0.032$ & 7 & 4 & $0.032 \pm 0.031$ \\
\hline Nilgai & 1 & 0 & 0.019 & 0 & 0 & - \\
\hline Blackbuck & 1 & 0 & 0.017 & 0 & 0 & - \\
\hline Browsers & 37 & 8 & & 39 & 16 & \\
\hline Moose & 14 & 3 & $0.039 \pm 0.008$ & 9 & 3 & $0.022 \pm 0.006$ \\
\hline Okapi & 7 & 1 & $0.062 \pm 0.014$ & 11 & 5 & $0.045 \pm 0.010$ \\
\hline Roe deer & 0 & 1 & 0.045 & 0 & 0 & - \\
\hline Dik-dik & 8 & 2 & $0.076 \pm 0.014$ & 6 & 4 & $0.04 \pm 0.016$ \\
\hline Duikers & 4 & 1 & $0.048 \pm 0.010$ & 3 & 2 & $0.039 \pm 0.008$ \\
\hline Mouse deer & 4 & 0 & $0.051 \pm 0.006$ & 3 & 1 & $0.046 \pm 0.004$ \\
\hline Intermediate feeder & 23 & 7 & & 85 & 23 & \\
\hline Anoa & 4 & 0 & $0.081 \pm 0.011$ & 4 & 0 & $0.039 \pm 0.008$ \\
\hline Reindeer & 5 & 3 & $0.045 \pm 0.014$ & 4 & 0 & $0.020 \pm 0.0004$ \\
\hline Gazelles & 6 & 0 & $0.100 \pm 0.015$ & 6 & 0 & $0.056 \pm 0.012$ \\
\hline Goats & 8 & 4 & $0.100 \pm 0.034$ & 53 & 16 & $0.027 \pm 0.007$ \\
\hline lbex & 0 & 0 & - & 17 & 7 & $0.054 \pm 0.021$ \\
\hline
\end{tabular}

Pred: prediction; Valid: validation 
Table 2 Summary statistics of feed and animal attributes used in prediction and validation of passage rates

\begin{tabular}{|c|c|c|c|c|c|c|c|c|c|c|}
\hline & \multicolumn{5}{|c|}{ Solid passage rate model } & \multicolumn{5}{|c|}{ Liquid passage rate model } \\
\hline & $\mathrm{N}$ & $\operatorname{Max}$ & Min & Mean & SD & $\mathrm{N}$ & $\operatorname{Max}$ & Min & Mean & SD \\
\hline Urea $(\mathbf{g} / \mathbf{k g})$ & 566 & 9.4 & 0 & 0.275 & 1.25 & 348 & 7 & 0 & 0.13 & 0.85 \\
\hline $\mathrm{DM}(\mathrm{g} / \mathrm{kg})$ & 566 & 966 & 70 & 742 & 265 & 348 & 957 & 154 & 746 & 263 \\
\hline NDF (g/kg) & 566 & 913 & 110 & 556 & 162 & 348 & 874 & 110 & 528 & 157 \\
\hline$A D F(g / k g)$ & 566 & 603 & 55 & 352 & 92 & 348 & 654 & 33.8 & 327 & 107 \\
\hline $\mathrm{CP}(\mathrm{g} / \mathrm{kg})$ & 566 & 295 & 25.7 & 130 & 57 & 348 & 710 & 19.4 & 142 & 79 \\
\hline ASH $(g / k g)$ & 566 & 138 & 20 & 76 & 18.3 & 348 & 197 & 20 & 81.6 & 26 \\
\hline DP (days) & 566 & 138 & 0 & 1.7 & 12.3 & 348 & 138 & 0 & 3 & 15 \\
\hline DL (days) & 566 & 290 & 0 & 17.8 & 45.9 & 348 & 233 & 0 & 5 & 29 \\
\hline MBM (kg) & 566 & 1100 & 2 & 374 & 286 & 348 & 900 & 2 & 411 & 283 \\
\hline PhyA & 566 & 1.5 & 0.07 & 0.629 & 0.315 & 348 & 1.5 & 0.125 & 0.58 & 0.26 \\
\hline APL & 566 & 3.28 & 0.87 & 1.28 & 0.53 & 348 & 2.4 & 1 & 1.09 & 0.26 \\
\hline FPR (per h) & 566 & 0.091 & 0.0007 & 0.033 & 0.0181 & 348 & 0.183 & 0.017 & 0.078 & 0.034 \\
\hline$a(g / k g)$ & 566 & 647 & 2 & 202 & 105 & & & & & \\
\hline b (g/kg) & 566 & 853 & 38 & 528 & 142 & & & & & \\
\hline$c($ per h) & 566 & 0.174 & 0.010 & 0.049 & 0.026 & & & & & \\
\hline$P D_{1 / 2 \text { life }}(g / k g)$ & 566 & 789 & 50 & 452 & 115 & & & & & \\
\hline$P D(g / k g)$ & 566 & 964 & 69 & 704 & 169 & & & & & \\
\hline
\end{tabular}

a: rapidly degradable water soluble fraction of fibre; ADF: acid detergent fibre; APL: animal production level; $\mathrm{b}$ : slowly degradable portion of the insoluble fraction of fibre; $c$ : rate of degradation of the " $b$ " fraction; CP: crude protein; DL: days in lactation; DM: dry matter; DP: days pregnant; FPR: fractional passage rate; MBM: mature body mass; NDF: neutral detergent fibre; PhyA: physiological age; $\mathrm{PD}_{1 / 2}$ life: potential degradability at half-life; PD: potential degradability.

Correlation coefficients of the input variables used in model development for liquid passage rates were weak $(R<0.5)$ and significant. However, strong correlations $(R>0.5)$ were observed between APL and days into lactation, body mass and mature bodyweight, ADF and NDF, body mass and physiological age, and days in lactation and days in pregnancy (Table 3). Correlation coefficients of input variables used in model development for solid passage rates were weak $(R<0.5)$, yet significant.

Strong $(R>0.5)$ and significant correlations were used in model development for solid passage rates. Animal factors that had strong correlations were APL and days in lactation, body mass and mature bodyweight, body mass and physiological age, days in lactation and body mass, APL and BM, APL and physiological age, mature body mass and feeding type. Feed factors that had correlations that were $>0.5$ were $A D F$ and NDF, PD and $b, C P$ and rate of degradation, DM and silage, CP and ADF, CP and NDF, PD at half-life and ' $a$ ', PD at half-life, and PD. The correlation of $>0.5$ between body mass and silage was unexpected (Table 3), given that body mass is an animal factor and silage a feed factor. Weak correlation coefficients indicated that input variables did not strongly influence one another in liquid and solid passage rate prediction. Significance of weak correlations was a result of the large number of observations used in model development.

The regression relationship between the observed $(Y)$ and predicted $(X)$ liquid passage rates $(p e r h)$ in model development was $Y=-0.0013( \pm 0.0024)+1.004( \pm 0.0295) X(n=261$, RMSE $=0.0142)$, accounting for $82 \%$ of the variation in prediction. The intercept $(P=0.5863)$ and slope $(P=0.8818)$ were not different from 0 and 1, respectively (Figure 2a). A plot of residual liquid passage rate against predicted liquid passage rate assessing the mean bias (intercept) and linear bias (slope) of the model in predicting liquid passage rate (Figure 2b) is given in this equation: $Y=-0.0031( \pm 0.00241)+0.0044( \pm 0.02948) \times\left(R^{2}=0.0001, R M S E=\right.$ 0.01422). The intercept $(P=0.5863)$ and slope $(P=0.8818)$ from the residual plot were not different from zero. It can be observed from the plot that with the exception of six outliers, residuals showed no obvious pattern on the horizontal axis. A plot of residual liquid passage rate against observed liquid passage rate 
assessed the goodness of predictions (Figure 2c) showing that residual liquid passage rate increased with increasing liquid passage rate. The regression relationship between the observed $(Y)$ and predicted $(X)$ liquid passage rates (per $h)$ in model validation using unseen data was $Y=0.02301( \pm 0.00557)+0.767( \pm$ $0.06178) X(n=87, R M S E=0.02105)$. This equation accounted for $64 \%$ of the variation in unseen data. The intercept and slope were significantly different from $0(P=0.0001)$ and $1(P=0.0003)$, respectively (Figure 2d).

The regression relationship between the observed $(Y)$ and predicted $(X)$ solid passage rates $(p e r h)$ in model development was $Y=-0.0014( \pm 0.00128)+1.005( \pm 0.0348) X(n=424$, RMSE $=0.01047)$, accounting for $66 \%$ of the variation in prediction. The intercept $(P=0.2753)$ and slope $(P=0.8823)$ were not different from 0 and 1, respectively (Figure 3a). A plot of residual solid passage rate against predicted solid passage rate assessing the mean bias (intercept) and linear bias (slope) of the model in predicting solid passage rate (Figure $3 \mathrm{~b})$ had the equation: $\mathrm{Y}=-0.0014( \pm 0.00128)+0.00516( \pm 0.03482) \times\left(R^{2}=0.0001\right.$, RMSE $=0.01047)$. The intercept $(P=0.2753)$ and slope $(P=0.8823)$ of the residual plot were not different from zero. It can be observed from the plot that residuals formed a cone shaped cluster on the horizontal axis. A plot of residual solid passage rate against observed solid passage rate assessed the goodness of the predictions (Figure $3 \mathrm{c}$ ). The residual solid passage rate increased with increasing solid passage rates. The regression relationship between the observed $(Y)$ and predicted $(X)$ solid passage rates $(p e r h)$ in model validation was: $Y=0.00476( \pm 0.00323)+0.888( \pm 0.08763) X(n=142, R M S E=0.01375)$, accounting for only $42 \%$ of the variation in unseen data. The intercept and slope were not different from $0(P=0.1429)$ and $1(P=0.2049)$, respectively (Figure $3 \mathrm{~d})$. Three outliers were observed for muskoxen in validation.

\section{Discussion}

Passage rates are affected by a wide variety of factors that have different effects. Passage rate is a function of animal species (Lechner et al., 2010), level of feeding (Seo et al., 2006; Mazzenga et al., 2009), forage to concentrate ratio (Bartocci et al., 1997), feeding behaviour (Okine et al., 1998), ambient temperature (Chaiyabutr et al., 1987; Bartocci et al., 1997), buffer content (Cappellozza et al., 2013), ionophores (Schelling et al., 1984), water intake (Varga \& Harpster, 1995), roughage quality (De Vega \& Poppi, 1997), animal reproductive state (Larsen et al., 2009), particle size and functional specific gravity (Poppi et al., 1980; Lechner-Doll et al., 1991), tannin content in diet (Silanikove et al., 2001; Al-Kindi et al., 2016), and diet or feed compositional attributes (Nsahlai et al., 1999). Ideally, passage rate prediction equations should be low-input, easy-to-use models that incorporate easy-to-measure input variables. However, limiting input variables may result to lower accuracy in predicting passage rates for diverse classes of ruminants. Developed models in this study are not low input models. However, input variables are fairly easy to compute.

All models developed in this study had slopes equal to 1 and intercepts at 0 . Coupled with high precision, all prediction models accounted for large amounts of variation in unknown observations. Few, if any, models developed thus far have achieved such high precision in predicting both solid and liquid passage rates for 17 ruminant animal species (wild and domesticated) from a wide range of climatic regions using a single model. In all model predictions and validations, all classes of ruminants were clustered along the ideal prediction line. A couple of sporadic outliers in prediction and validation of the solid passage rates from ibex and muskoxen, respectively, are clearly identifiable. For both ruminant species, passage rate was grossly underpredicted by these models, particularly as these animals inhabit a cold climate. Ambient temperature ranges outside the thermo-neutral zone lead to physiological responses, which alter passage of fluid and solid through the rumen. Lowering temperatures to freezing increased passage rate of solid by $21 \%$ (Kennedy, 1985) and increased temperatures doubled passage rates of liquid (Chaiyabutr et al., 1987). The degree of change in passage rates as a result of temperature fluctuations is exceedingly high and the direction of change is unpredictable. These suggest that studies need to consider season and place of study to index ambient temperature.

Most studies have developed passage rate prediction equations with good coefficients of determination ( $R^{2}$ value) that accounted for a greater portion of the variation using intake (of DM or NDF) as major input variables. DM intake alone is normally the most important factor affecting solid and liquid passage rates (Seo et al., 2009) accounting for just over $20 \%$ of the variation in passage rate prediction models. However, given that the main application of passage rate equations would be to predict dry matter intake (DMI) and microbial yields, inclusion of intake when developing passage rate models may be questionable. To eliminate this bias, neither prediction model developed in this study incorporated feed intake as an input variable. 
Table 3 Pearson correlations between input factors used in solid (above diagonal) and liquid (below diagonal) model development

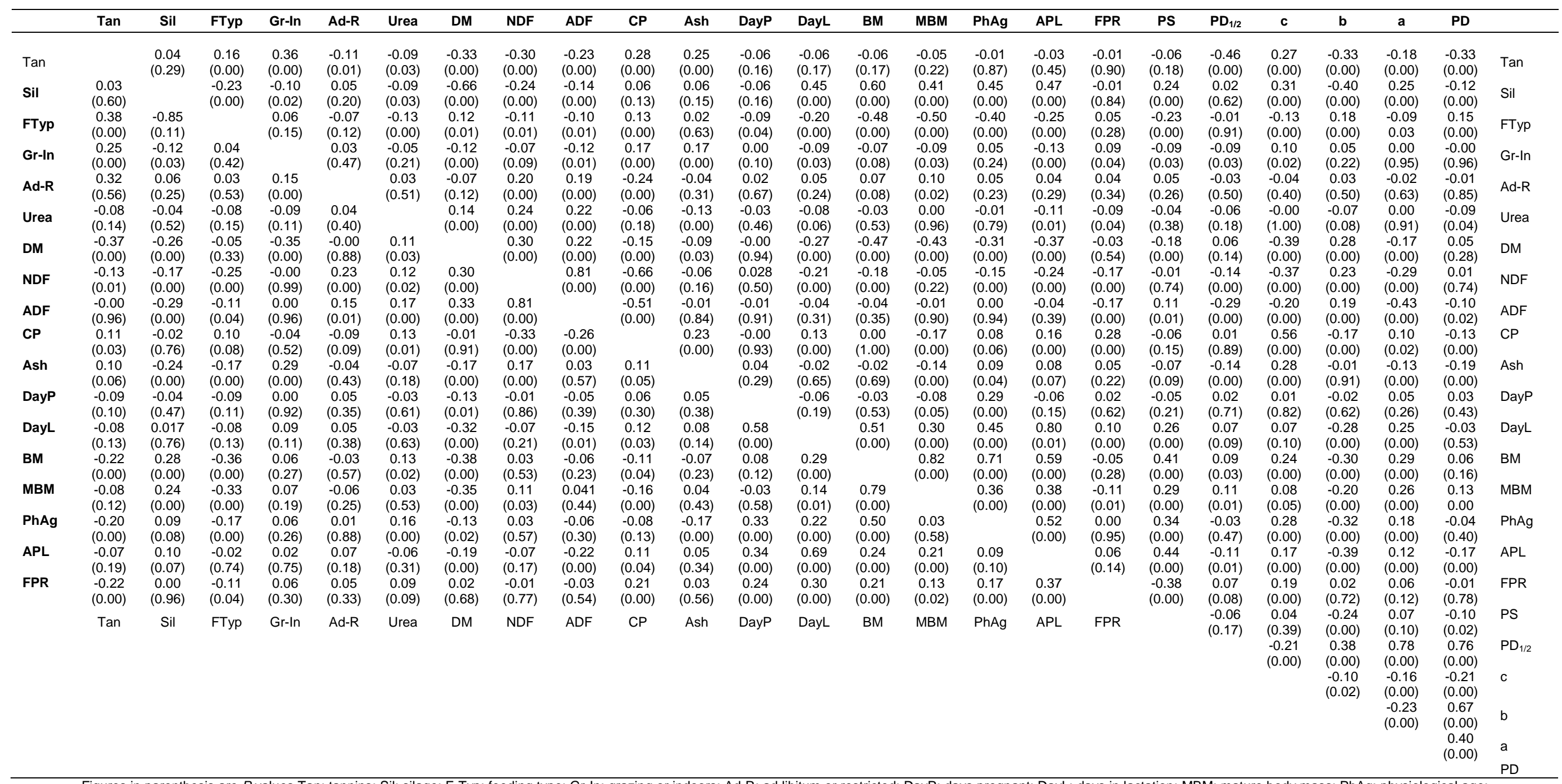

Figures in parenthesis are $P$ values Tan: tannins; Sil: silage; F-Typ: feeding type; Gr-In: grazing or indoors; Ad-R: ad
APL: animal production level; FPR: fractional passage rate; PS: particle size; $\mathrm{PD}_{1 / 2}:$ potential degradability at half-life 


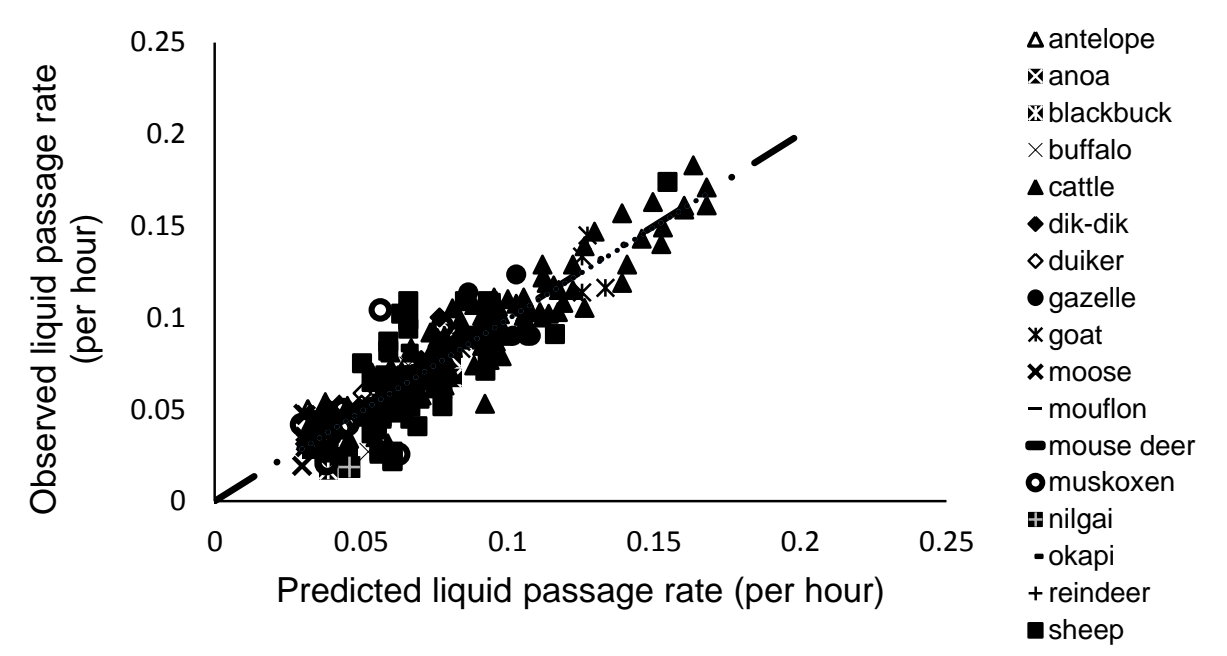

Figure 2a Relationship between the observed and predicted liquid passage rates for model development

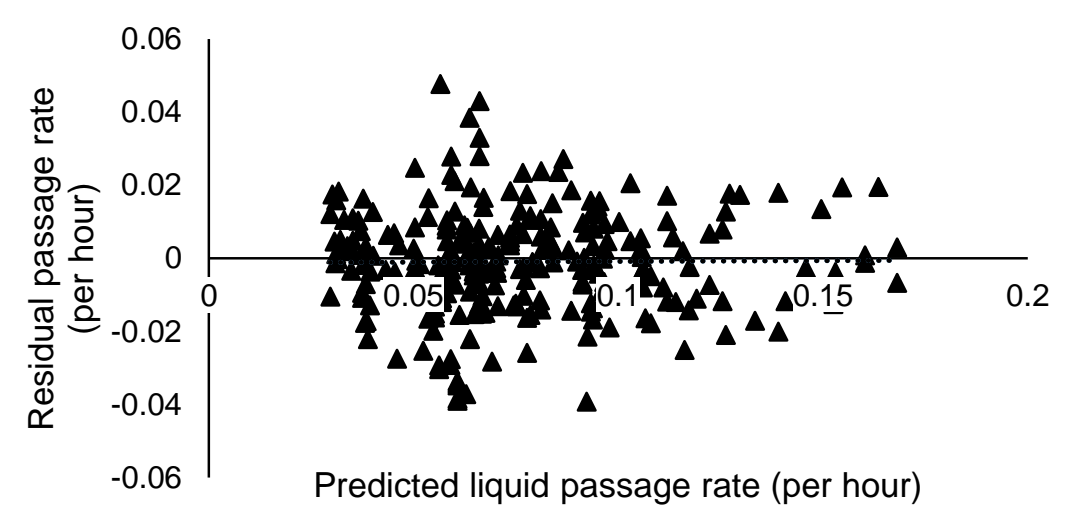

Figure 2b Residual (observed-predicted) plot against predicted liquid passage rate to test model bias in prediction

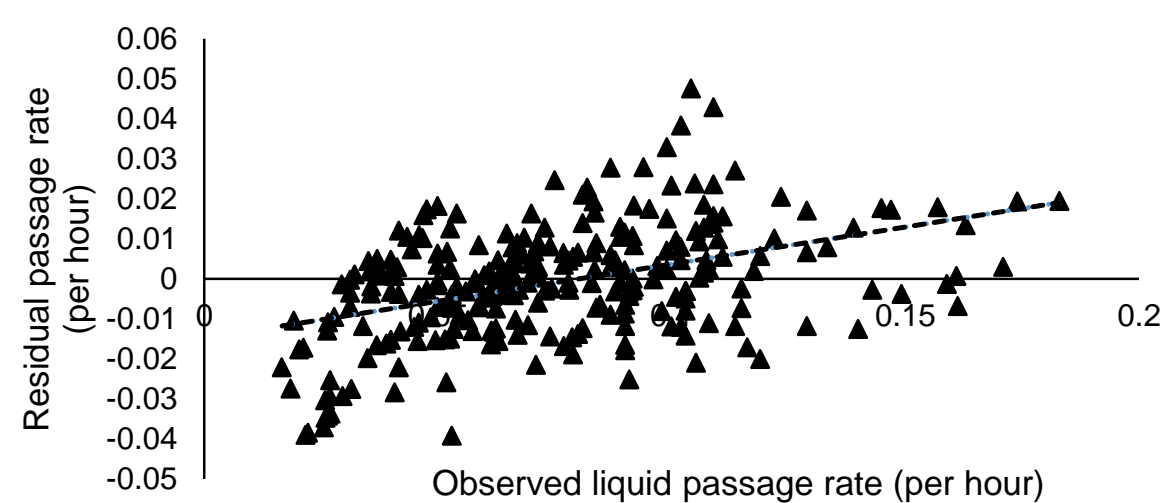

Figure 2c Residual (observed-predicted) plot against observed liquid passage rate

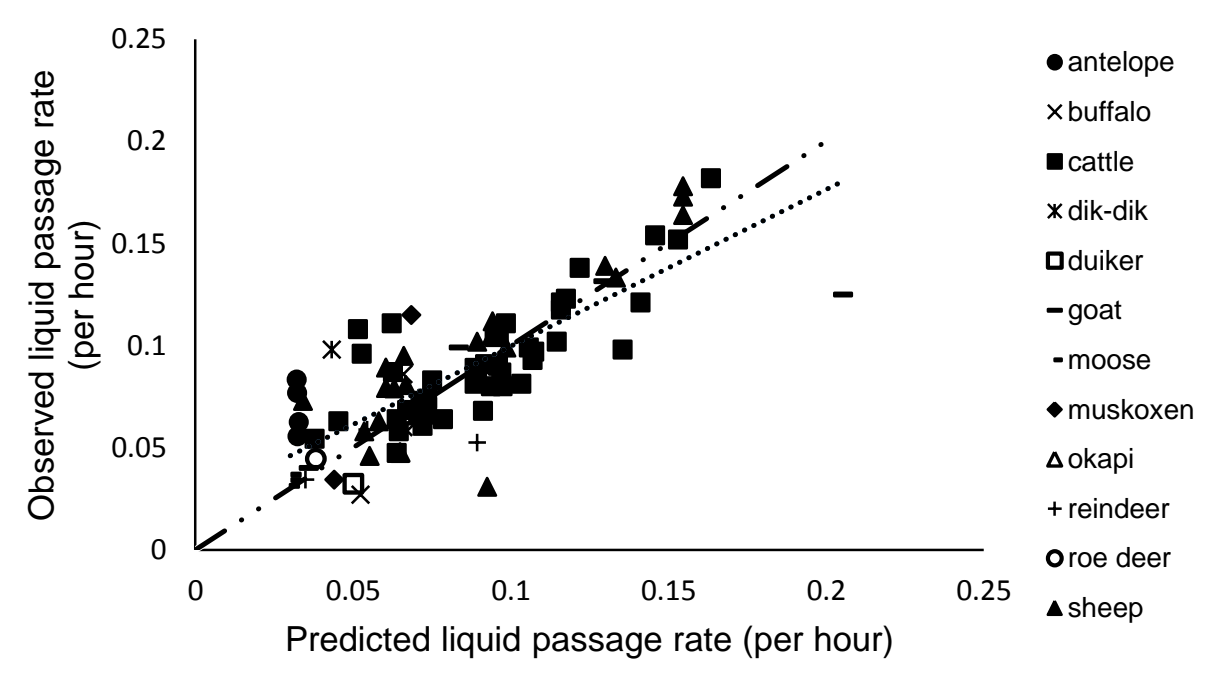

Figure 2d Relationship between the observed and predicted liquid passage rates for model validation 


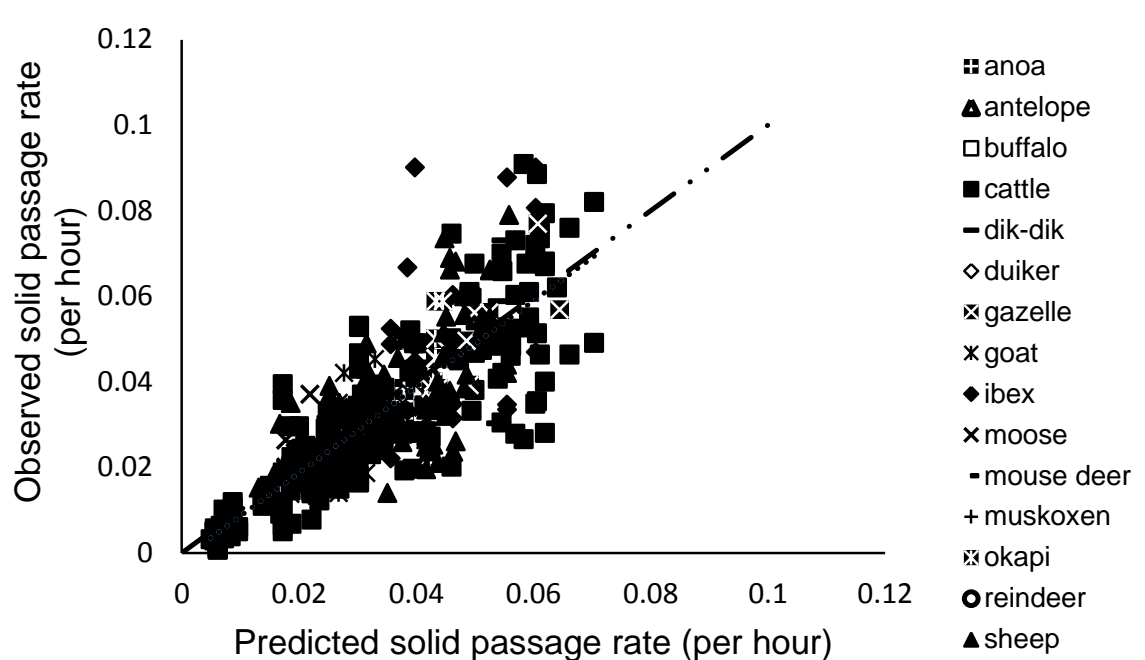

Figure 3a Relationship between the observed and predicted solid passage rates for model development

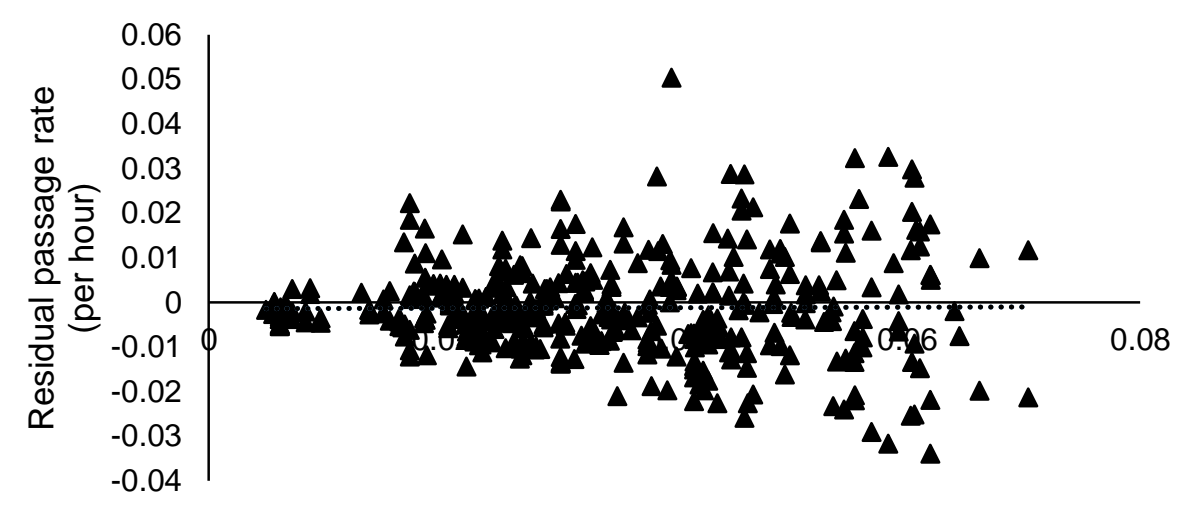

Predicted solid passage rate (per hour)

Figure $\mathbf{3 b}$ Residual (observed-predicted) plot against predicted solid passage 1 rate to test model bias in prediction

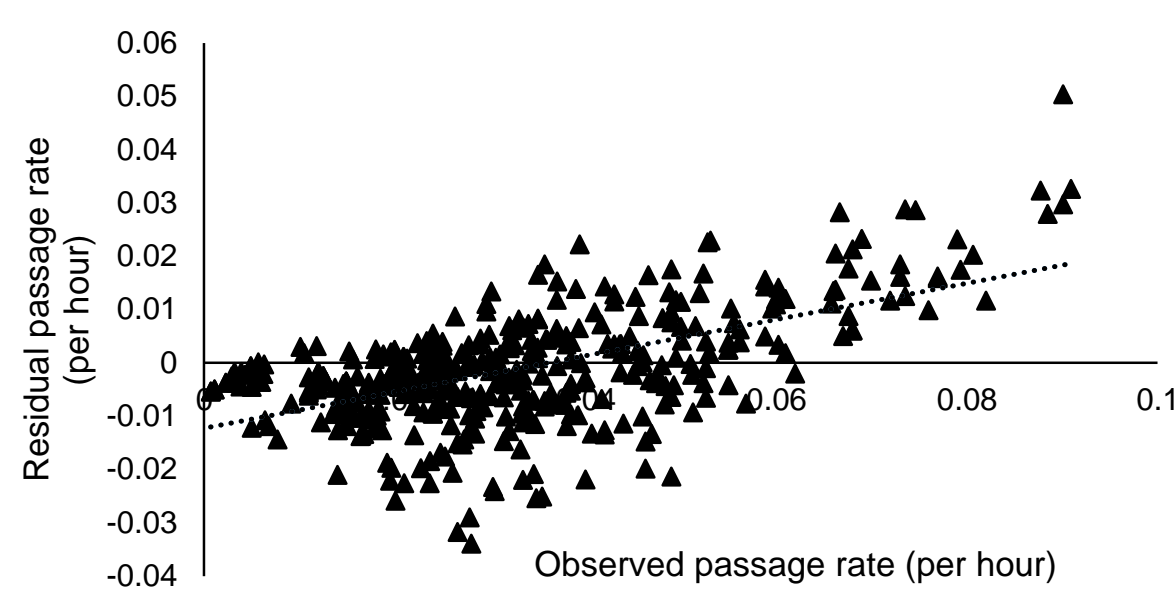

Figure 3c Residual (observed-predicted) plot against observed solid passage rate

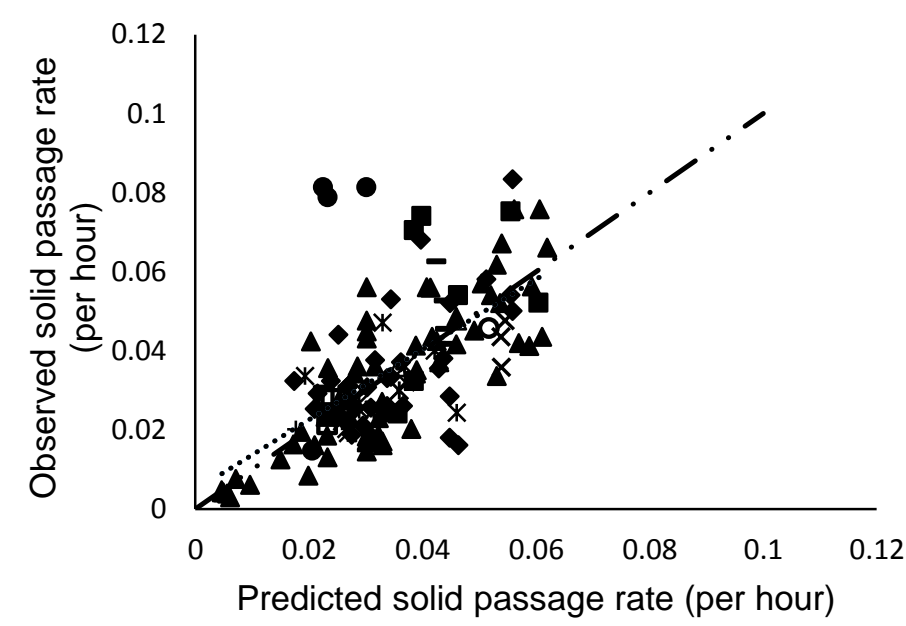

口antelope

$\Delta$ cattle

X dik-dik

$\Delta$ duiker

* goat

ibex

+ moose

omouse deer

- muskoxen

- okapi

$\checkmark$ sheep

Figure 3d Relationship between the observed and predicted solid passage rates for model validation 
Unlike models developed by Seo et al. (2006), models for predicting passage rates for liquid in this study had few lactating and pregnant cattle and sheep, and other ruminants had no pregnant or lactating animals. This may limit the use of models developed in this study in predicting passage rates for pregnant and/or lactating dairy cows and other ruminants. Since most studies did not report bodyweight changes, assumptions that animals in those studies were at maintenance level may be biased. Obtaining bodyweight changes in those studies and computing animal production level (APL) would have accounted for some variation in model development.

Seo et al. (2006) excluded observations from wild ruminants and animals of body mass less than 100 $\mathrm{kg}$, and datasets from animals that had DMI of less than $10 \mathrm{~g} / \mathrm{kg}$ body weight, thus limiting the conditions to which their equations can be applied. Similarly, models by Krizsan et al. (2010) used passage rate observations only from trials in Europe and the United States. These models may be applicable to ruminants from temperate areas, but not to those from tropical regions. However, model development in this study used a wide range of ruminant species of differing body mass, from one of the smallest ruminants in the world (mouse deer, averaging $1.6 \mathrm{~kg}$ in body mass) to large ruminant animals averaging over $1238 \mathrm{~kg}$ in body mass. The implication is that the models developed in this study could be used to predict passage rates for any size, class and type of ruminant animal under any climatic condition with considerable precision.

Particle density is one of the major factors affecting solid particle passage out of the rumen (Hristov et al., 2003). It was assumed that high potential degradability at half-life would increase gas production in solid particles, rendering them buoyant. This propels them away from the reticulo-rumen orifice, reducing passage rates. However, correlation results showed that passage rates of solids tended to increase with degradability at half-life, defeating the use of this variable. Thus, rapid reduction in particle size overshadows the effect of buoyancy in reducing passage rates. This may show some limitations in use of artificial neural networks in capturing biological phenomena.

Based on coefficients of determination, models for predicting liquid passage rates accounted for $94 \%$ (Seo et al., 2006), 84\%, and 83\% (Seo et al., 2007) of the variation in prediction. Residual plots (residuals against predicted passage) of the liquid prediction model, together with that of Seo et al. $(2006$, ) revealed that models from both studies had no linear or mean bias in prediction of liquid passage rates. Although the model for liquid passage in this study accounted for less variation than models of Seo et al. (2006), it performed better in model validation using an independent dataset by accounting for three times the variation. Even though the liquid model in this study accounted for less variation in validation compared with that of Seo et al. (2009) $\left(R^{2}=0.81\right)$, the study by Seo et al showed a linear bias in prediction of liquid passage rates.

A comparison between the coefficients of determination from this study (mathematical modelling) and those from other studies (mainly statistical modelling) showed more or less similar results. Seo et al. (2006) developed passage rate prediction equations for various ruminant types using DMI of forage, and of forages and concentrates per unit of body mass. Their equations for predicting solid passage rate explained $+21 \%$ (for forages) and $+29 \%$ (for concentrates) more variation than the model developed in this study. However, the solid passage prediction model developed in this study explained more variation compared with other models, which accounted for only 37\% (Nsahlai \& Apaloo, 2007), 53\% for forages (Cannas et al., 2004), and $65 \%$ for concentrates (Cannas et al., 2004), of observed variation. On validation using independent datasets, models managed to account for only $39 \%$ (forages) and 40\% (concentrate) of the variation (Seo et al., 2006), which is lower than findings in this study for the solid passage rate prediction model.

On the contrary, evaluation of two prediction equations developed for forages from Seo et al.'s (2009), models explained more variation (66 and $86 \%$ ) than the solid passage prediction model in the current study, although RMSE in validation were similar to those of this study. Models by Seo et al. (2009) had superior coefficients of determination for both liquids and solids compared with models in this study when evaluated with an independent dataset. First, models of Seo et al. (2009) accounted for one of the most critical, but neglected factors that influence passage rates, that is, feeding behaviour. This study did not include feeding behaviour as an input variable for passage rate predictions owing to unavailability of information on feeding behaviour in all studies. Based on the influence of feeding behaviour on frequencies and amplitudes of reticulo-rumen contractions, it seems possible to develop prediction models for feeding behaviour; and then to input feeding behaviour variables into the solid and liquid passage rate prediction equations (Sauvant et al., 1996; Seo et al., 2007; Seo et al., 2009). However, this warrants further study. Second, higher coefficients of determination of models by Seo et al. (2009) in evaluation may have been because of limited ruminant classes and limited intake level used in the evaluation compared with the wide range of ruminant animals used in this study.

Ruminant animals grazing on tropical grasslands of Africa are subjected to feed shortages in the dry seasons because of droughts as a result of climate change. It is thought that ruminants exposed to starvation may retain digesta for long durations in the rumen to render digestion more efficient. Hence, these 
ruminants generally elicit slower rates of passage of both solid and liquid in the rumen, and higher rumen fill levels (Nsahlai et al., 1996) than temperate ruminants. Owing to impending feed shortages that are consequent to drought, models developed for use in the future should consider accounting for hunger in prediction to accommodate changes in environmental conditions. Precision in predicting passage rates of digesta for ruminant animals could be further improved by considering factors such as degree of hunger, water intake, feeding behaviour and climatic conditions.

\section{Conclusion}

Both solid and liquid passage rate prediction models achieved good accuracy, as all ruminants were clustered along the ideal prediction line. The study developed more precise prediction models for solid and liquid passage rates for ruminants fed on a variety of diets and feeds in various climatic regions. More work needs to refine current prediction models to achieve precise prediction of passage rates of digesta in the rumen. The success of artificial neural networks in the prediction of solid and liquid passage rates in this study may pave the way for predicting roughage intake in ruminants from different climatic regions using one prediction model.

\section{Acknowledgments}

This study was financially supported by the National Research Foundation of the Republic of South Africa (Project name: Intake of roughage by ruminant herbivores, GUN number: 87738 ).

\section{Authors' Contributions}

IVN conceptualised the idea. IVN and MM designed the study, collected and analysed the data, interpreted the results and drafted the article. EBGK programmed and developed the ANN models, and drafted the ANN modelling section of the methodology. All authors provided critical revision of the manuscript.

\section{Conflict of interest declaration}

We affirm that all the authors of this manuscript agree to the submission and the manuscript has not been submitted to, published in or considered for publication anywhere else.

\section{Literature used in creation of passage rate datasets}

Abdullah et al. (1991), Abdullah et al. (2012), Abule et al. (1995), Adams et al. (1981), Adams et al. (1987), Arthun et al. (1992), Barboza et al. (2006), Bartocci et al. (1997), Bayat et al. (2010), Bayat et al. (2011), Behrend et al. (2004), Bonsi et al. (1996), Boudon et al. (2009), Branine \& Galyean (1989), Bruining et al. (1998), Burns et al. (1997), Cappellozza et al. (2013), Castle et al. (1955), Chaiyabutr et al. (1987), Cherney et al. (1991), Clauss et al. (2011), Coleman et al. (2003), De Vega \& Poppi (1997), Dhanoa et al. (1985), Dittmann et al. (2015), Erdman et al. (1987), Faichney et al. (1989), Flores-Miyamoto et al. (2005), Frotschel \& Amos (1991), Frotschel et al. (1987), Grant \& Cotanch (2011), Gross et al. (1996), Gunter et al. (1990), Haaland \& Tyrrell (1982), Hebel et al. (2011), Hjeljord et al. (1982), Huhtanen et al. (2007), Hummel et al. (2005; 2008; 2015), Judkins \& Stobart (1988), Judkins et al. (1987), Kammes \& Allen (2012), Kaske \& Groth (1997), Kaske \& Midasch (1997), Kattnig et al. (1992), Koster et al. (1996), Kovacs et al. (1998), Lechner et al. (2009; 2010), Ledoux et al. (1985), Leite et al. (2015), McCollum \& Galyean (1985), Merchen et al. (1986), MolinaAlcaide et al. (2000), Moolchand et al. (2013), Moore et al. (1990), Mulligan et al. (2002), Ndlovu \& Buchanan-Smith (1985), Nsahlai et al. (1999), Okeke et al. (1983), Oshita et al. (2008), Panjaitan et al. (2010), Pond et al. (1989), Rankins \& Bransby (1995), Robles et al. (1981), Schlecht et al. (2007), Shem et al. (1995), Silanikove et al. (1993), Silanikove et al. (2001), Tafaj et al. (2001), Varga \& Prigge (1982), Warren et al. (1974), Yayota et al. (2009).

\section{References}

Abdou, N., 2016. Effect of roughage processing and feeding level on production, reproduction, and growth performance of the Red Maradi goat. PhD thesis, University of KwaZulu-Natal, South Africa.

Abdullah, N., Ho, Y.W., Mahyuddin, M. \& Jalaludin, S., 1991. Studies in fibre digestion and passage rate of liquid and solid in cattle and buffaloes. J. Anim. Sci. 4 (2), 137-141.

Abdullah, N., Liang, J.B. \& Ho, Y.W., 2012. Effects of diets of differing fiber contents on digestibility, passage rate of digesta and heat production in lesser mouse deer (Tragulus javanicus). Mamm. Biol. 77 (6), 385-390.

Abule, E., Umunna, N.N., Nsahlai, I.V., Osuji, P.O. \& Alemu, Y., 1995. The effect of supplementing teff (Eragrostis tef) straw with graded levels of cowpea (Vigna unguiculata) and lablab (Lablab purpureus) hays on degradation, rumen particulate passage and intake by crossbred (Friesian $\times$ Boran (zebu)) calves. Livest. Prod. Sci. 44 (3), 221-228.

Adams, D.C., Galyean, M.L. \& Kiesling, H.E., 1981. Influence of viable yeast culture, sodium bicarbonate and monensin on liquid dilution rate, rumen fermentation and feedlot performance of growing steers and digestibility in lambs. J. Anim. Sci. 53 (3), 780-789.

Adams, D.C., Cochran, R. \& Currie, P., 1987. Forage maturity effects on rumen fermentation, fluid flow, and intake in grazing steers. J. Range Manag. 404-408.

Adebayo, R.A., 2015. Effect of roughage quality and period of meal termination on rumen fill. MSc thesis, University of KwaZulu-Natal, South Africa. 
ADW, 2014. Animal Diversity Web (online). University of Michigan. Accessed 26 June, 2016 at http://animaldiversity.org/accounts/Mammalia/.

AFRC, 2003. Energy and protein requirements of ruminants. Advisory manual prepared by AFRC Technical Committee on Responses to Nutrients. CAB International, Wallingford, UK.

Al-Kindi, A., Schiborra, A., Buerkert, A. \& Schlecht, E., 2016. Effects of quebracho tannin extract and activated charcoal on nutrient digestibility, digesta passage and faeces composition in goats. J. Anim. Physiol. Anim. Nutr. DOI:10.1111/jpn.12461.

Allen, M.S., 1996. Physical constraints on voluntary intake of forages by ruminants. J. Anim. Sci. 74 (12), $3063-3075$.

Arkive, 2016. Explore mammal species (online), Arkive Organisation. Accessed 27 June 2016 at http://www.arkive.org/explore/species/mammals.

Arthun, D., Holechek, J.L., Wallace, J.D., Gaylean, M.L. \& Cardenas, M., 1992. Forb and shrub effects on ruminal fermentation in cattle. J. Range Manag. 1, 519-522.

AWF (African Wildlife Fund), 2016. Wildlife conservation (online). Accessed 26 June, 2016 at http://www.awf.org/wildlifeconservation/all.

Barboza, P.S., Peltier, T.C. \& Forster, R.J., 2006. Ruminal fermentation and fill change with season in an arctic grazer: responses to hyperphagia and hypophagia in muskoxen (Ovibos moschatus). Physiol. Biochem. Zool. 79 (3), 497-513.

Bartocci, S., Amici, A., Verna, M., Terramoccia, S. \& Martillotti, F., 1997. Solid and fluid passage rate in buffalo, cattle and sheep fed diets with different forage to concentrate ratios. Livest. Prod. Sci. 52 (3), 201-208.

Baumont, R., Brun, J.P. \& Dulphy, J.P., 1989. Influence of the nature of hay on its ingestibility and the kinetics of intake during large meals in sheep and cows. Proc. XVI Intl. French Grassland Soc. 787.

Bayat, A.R., Rinne, M., Kuoppala, K., Ahvenjärvi, S. \& Huhtanen, P., 2010. Ruminal large and small particle kinetics in dairy cows fed red clover and grass silages harvested at two stages of growth. Anim. Feed Sci. Technol. 155, 8698.

Bayat, A.R., Rinne, M., Kuoppala, K., Ahvenjärvi, S. \& Huhtanen, P., 2011. Ruminal large and small particle kinetics in dairy cows fed primary growth and regrowth grass silages harvested at two stages of growth. Anim. Feed Sci. Technol. 165, 51-60.

Beefmagazine, 2015. Feed composition table. http://beefmagazine.com/sitefiles/beefmagazine.com/files/uploads/2015/02/2015-BEEF-Magazine-Feed-Comp-Tables.pdf.

Behrend, A., Lechner-Doll, M., Streich, W.J. \& Clauss, M., 2004. Seasonal faecal excretion, gut fill, liquid and particle marker retention in mouflon (Ovis ammon musimon), and a comparison with roe deer (Capreolus capreolus). Acta Theriol. 49 (4), 503-515.

Behzadi, M.R.B. \& Aslaminejad, A.A., 2010. A comparison of neural network and nonlinear regression predictions of sheep growth. J. Anim. Vet. Adv. 9 (16), 2128-2131.

Bonsi, M.L.K., Tuah, A.X., Osuji, P.O., Nsahlai, I.V. \& Umunna, N.N., 1996. The effect of protein supplement source or supply pattern on the intake, digestibility, rumen kinetics, nitrogen utilisation and growth of Ethiopian Menz sheep fed teff straw. Anim. Feed Sci. Technol. 64, 11-25.

Boudon, A., Peyraud, J.L., Faverdin, P., Delagarde, R., Delaby, L. \& Chaves, A.V., 2009. Effect of rumen fill on intake of fresh perennial ryegrass in young and mature dairy cows grazing or zero-grazing fresh perennial ryegrass. Animal 3 (12), 1706-1720.

Branine, M.E. \& Galyean, M.L., 1990. Influence of grain and monensin supplementation on ruminal fermentation, intake, digesta kinetics and incidence and severity of frothy bloat in steers grazing winter wheat pasture. J. Anim. Sci. 68, 1139-1150.

Bruining, M., Bakker, R., Van Bruchem, J. \& Tamminga, S., 1998. Rumen digesta kinetics in dairy cows fed grass, maize and alfalfa silage. 1. Comparison of conversional, steady state and dynamic methods of estimate microbial degradation, comminution and passage of particles. Anim. Feed Sci. Technol. 73, 37-58.

Burns, J.C., Pond, K.R., Fisher, D.S. \& Luginbuhl, J.M., 1997. Changes in forage quality, ingestive mastication, and digesta kinetics resulting from switchgrass maturity. J. Anim. Sci. 75, 1368-1379.

Cannas, A., Tedeschi, L.O., Fox, D.G., Pell, A.N. \& Van Soest, P.J., 2004. A mechanistic model for predicting the nutrient requirements and feed biological values for sheep. J. Anim. Sci. 82 (1), 149-169.

Cappellozza, B.I., Bohnert, D., Schauer, C., Falck, S., Vanzant, E., Harmon, D. \& Cooke, R., 2013. Daily and alternate day supplementation of urea or soybean meal to ruminants consuming low quality cool-season forage: II. Effects on ruminal fermentation. Livest. Sci. 155 (2), 214-222.

Castle, E.J., 1956. The rate of passage of foodstuffs through the alimentary tract of the goat. Br. J. Nutr. 10 (2), 115-125.

Chaiyabutr, N., Buranakarl, C., Muangcharoen, V., Loypetjra, P. \& Pichaicharnarong, A., 1987. Effects of acute heat stress on changes in the rate of liquid flow from the rumen and turnover of body water of swamp buffalo. J. Agric. Sci. 108 (3), 549-553.

Cherney, D.J, Mertens, D.R. \& Moore, J.E., 1991. Fluid and particulate retention times in sheep as influenced by intake level and forage morphological composition. J. Anim. Sci. 69 (1), 413-422.

Cillie, B., 2009. The mammal guide of Southern Africa. Briza, Pretoria, South Africa.

Clauss, M., Lunt, N., Ortmann, S., Plowman, A., Codron, D. \& Hummel, J., 2011. Fluid and particle passage in three duiker species. Eur. J. Wildl. Res. 57 (1), 143-148.

Coleman, S.W, Hart, S.P. \& Sahlu, T., 2003. Relationships among forage chemistry, rumination and retention time with intake and digestibility of hay by goats. Small Ruminant Res. 50 (1), 129-140.

Craninx, M., Fievez, V., Vlaeminck, B. \& De Baets, B., 2008. Artificial neural network models of the rumen fermentation pattern in dairy cattle. Comput. Electron. Agric. 60 (2), 226-238. 
De Vega, A. \& Poppi, D.P., 1997. Extent of digestion and rumen condition as factors affecting passage of liquid and digesta particles in sheep. J. Agric. Sci. 128 (2), 207-215.

Dhanoa, M.S., Siddons, R.C., France, J. \& Gale, D.L., 1985. A multicompartmental model to describe marker excretion patterns in ruminant faeces. Br. J. Nutr. 53, 663-671.

Dijkstra, J., Kebreab, E., Mills, J.A.N., Pellikaan, W.F., Lopez, S., Bannink, A. \& France, J., 2007. Predicting the profile of nutrients available for absorption: From nutrient requirement to animal response and environmental impact. Animal 1 (1), 99-111.

Dittmann, M.T., Hummel, J., Hammer, S., Arif, A., Hebel, C., Mueller, D.W., Fritz, J., Steuer, P., Schwarm, A., Kreuzer, M. \& Clauss, M., 2015. Digesta kinetics in gazelles in comparison to other ruminants: evidence for taxon specific rumen fluid throughput to adjust digesta washing to the natural diet. Comp. Biochem. Physiol. Part A Mol. Integr. Physiol. 185, 58-68.

Dong, R. \& Zhao, G., 2014. The use of artificial neural network for modelling in vitro rumen methane production using the CNCPS carbohydrate fractions as dietary variables. Livest. Sci. 162, 159-167.

Erdman, R.A., Vandersall, J.H., Russek-Cohen, E. \& Switalski, G., 1987. Simultaneous measures of rates of ruminal digestion and passage of feeds for prediction of ruminal nitrogen and dry matter digestion in lactating dairy cows. J. Anim. Sci. 64, 565-577.

Estes, R.D., 1993. The safari companion: A guide to watching African mammals. Russel Friedman Books, Halfway House, Johannesburg, South Africa.

Faichney, G.J., 1980. Measurement in sheep of the quantity and composition of rumen digesta and of the fractional outflow rates of digesta constituents. Aust. J. Agric. Res. 31 (6), 1129-1137.

Faichney, G.J., Poncet, C., Boston, R.C., Bernard, L., Pochet, S., Beaufort, M.T., Delval, E., Fabre, M., Pichon, P. \& Flechet, J., 1989. Passage of internal and external markers of particulate matter through the rumen of sheep. Reprod. Nutr. Dev. 29 (3), 325-237.

Feedipedia, 2016. Animal Feed Resources Information System. A programme by INRA, CIRAD, AFZ and FAO. http://www.feedipedia.org.

Flores-Miyamoto, K., Clauss, M., Ortmann, S. \& Sainsbury, A.W., 2005. Nutrition of captive lowland anoa (Bubalus depressicornis): A study on ingesta passage, intake, digestibility, and a diet survey. Zoo Biol. 24 (2), 125-134.

Fox, D.G., Tedeschi, L.O., Tylutki, T.P., Russell, J.B., Van Amburgh, M.E., Chase, L.E., Pell, A.N. \& Overton, T.R., 2004. The Cornell net carbohydrate and protein system model for evaluating herd nutrition and nutrient excretion. Anim. Feed Sci. Technol. 112 (1), 29-78.

Frandsen, R., 1992. Southern Africa's mammals: a field guide. Frandsen, Sandton, Johannesburg, South Africa.

Froetschel, M.E., Croom Jr, W., Hagler Jr, W., Argenzio, R., Liacos, J. \& Broquist, H., 1987. Effects of slaframine on ruminant digestive function: liquid turnover rate and fermentation patterns in sheep and cattle. J. Anim. Sci. 64 (4), 1241-1248.

Froetschel, M.E. \& Amos, H.E., 1991. Effects of dietary fiber and feeding frequency on ruminal fermentation, digesta water-holding capacity, and fractional turnover of contents. J. Anim. Sci. 69, 1312-1321.

Ganesan, R., Dhanavanthan, P., Kiruthika, C., Kumarasamy, P. \& Balasubramanyam, D., 2014. Comparative study of linear mixed-effects and artificial neural network models for longitudinal unbalanced growth data of Madras red sheep. Vet. World 7, 52-58.

Grant, R.J. \& Cotanch, K.W., 2012. Higher forage diets: dynamics of passage, digestion, and cow productive responses. William H. Miner Agricultural Research Institute, Chazy, NY.

Gross, J.E., Alkon, P.U. \& Demment, M.W., 1996. Nutritional ecology of dimorphic herbivores: Digestion and passage rates in Nubian Ibex. Oecologia 107 (2), 170-178.

Grovum, W.L., Phillips, G.D., 1973. Rate of passage of digesta in sheep. 5. Theoretical considerations based on physical model and computer simulation. Br. J. Nutr. 30 (2), 377-390.

Gunter, S., Judkins, M., Krysl, L., Broesder, J., Barton, R., Rueda, B. \& Holcombe, D., 1990. Digesta kinetics, ruminal fermentation characteristics and serum metabolites of pregnant and lactating ewes fed chopped alfalfa hay. J. Anim. Sci. 68 (11), 3821-3831.

Haaland, G. \& Tyrrell, H., 1982. Effects of limestone and sodium bicarbonate buffers on rumen measurements and rate of passage in cattle. J. Anim. Sci. 55 (4), 935-942.

Haykin S. 1998. Neural networks: A comprehensive foundation. 2nd edition. Macmillan, New York.

Hebel, C., Ortmann, S., Hammer, S., Hammer, C., Fritz, J., Hummel, J. \& Clauss, M., 2011. Solute and particle retention in the digestive tract of the Phillip's dikdik (Madoqua saltiana phillipsi), a very small browsing ruminant: Biological and methodological implications. Comp. Biochem. Physiol. Part A Mol. Integr. Physiol. 159, 284-290.

Hjeljord, O., Sundstøl, F. \& Haagenrud, H., 1982. The nutritional value of browse to moose. J. Wildl. Manag. 1, $333-343$.

Hofmann, R.R., 1989. Evolutionary steps of ecophysiological adaptation and diversification of ruminants: a comparative view of their digestive system. Oecologia Berl. 78 (4), 443-457.

Hristov, A.N., Ahvenjärvi, S., McAllister, T.A. \& Huhtanen, P., 2003. Composition and digestive tract retention time of ruminal particles with functional specific gravity greater or less than 1.02. J. Anim. Sci. 81 (10), 2639-2648.

Huhtanen, P., Asikainen, U., Arkkila, M. \& Jaakkola, S., 2007. Cell wall digestion and passage kinetics estimated by marker and in situ methods or by rumen evacuations in cattle fed hay 2 or 18 times daily. Anim. Feed Sci. Technol. 133 (3), 206-227.

Hummel, J., Clauss, M., Zimmermann, W., Johanson, K., Nørgaard, C. \& Pfeffer, E., 2005. Fluid and particle retention in captive okapi (Okapia johnstoni). Comparative Biochemistry and Physiology Part A: Molecular and Integrative Physiology 140 (4), 436-444. 
Hummel, J., Sudekum, K.H., Streich, W.J. \& Clauss, M., 2006. Forage fermentation patterns and their implications for herbivore ingesta retention times. Funct. Ecol. 20 (6), 989-1002.

Hummel, J., Steuer, P., Südekum, K.H., Hammer, S., Hammer, C., Streich, W.J. \& Clauss, M., 2008. Fluid and particle retention in the digestive tract of the addax antelope - adaptations of a grazing desert ruminant. Comp. Biochem. Physiol. Part A Mol. Integr. Physiol. 149, 142-149.

Hummel, J., Hammer, S., Hammer, C., Ruf, J., Lechenne, M. \& Clauss, M., 2015. Solute and particle retention in a small grazing antelope, the blackbuck (Antilope cervicapra). Comp. Biochem. Physiol. Part A Mol. Integr. Physiol. 182, 22-26.

Illius, A.W. \& Gordon, I.J., 1991. Prediction of intake and digestion in ruminants by a model of rumen kinetics integrating animal size and plant characteristics. J. Agric. Sci. 116 (1), 145-157.

Jenkins, T.G., Kaps, M., Cundiff, L.V. \& Ferrell, C.L., 1993. Estimates of mature weights and maturing rates for breed crosses. Roman L. Hruska U.S. Meat Animal Research Centre. Paper 331.

Judkins, M.B., Wallace, J.D., Galyean, M.L., Krysl, L.J. \& Parker, E.E., 1987. Passage rates, rumen fermentation, and weight change in protein supplemented grazing cattle. J. Range Manag. 100-105.

Judkins, M.B. \& Stobart, R.H., 1988. Influence of two levels of enzyme preparation on ruminal fermentation, particulate and fluid passage and cell wall digestion in wether lambs consuming either a $10 \%$ or $25 \%$ grain diet. J. Anim. Sci. 66, 1010-1015.

Kammes, K.L. \& Allen, M.S., 2012. Rates of particle size reduction and passage are faster for legume compared with cool-season grass, resulting in lower rumen fill and less effective fiber. J. Dairy Sci. 95, 3288-3297.

Kaske, M. \& Groth, M.K.A., 1997. Changes in factors affecting the rate of digesta passage during pregnancy and lactation in sheep fed on hay. Reprod. Nutr. Dev. 37, 573-588.

Kaske, M. \& Midasch, A., 1997. Effects of experimentally impaired reticular contractions on digesta passage in sheep. Br. J. Nutr. 78, 97-110.

Kattnig, R.M., Pordomingo, A.J., Schneberger, A.G., Duff, G.C. \& Wallace, J.D. 1992. Influence of saline water on intake, digesta kinetics, and serum profiles of steers. J. Range Manag. 45 (6), 514-518.

Kennedy, P.M., 1985. Influences of cold exposure on digestion of organic matter, rates of passage of digesta in the gastrointestinal tract, and feeding and rumination behaviour in sheep given four roughage diets in the chopped, or ground or pelleted form. Br. J. Nutr. 53 (1), 159-173.

Köster, H.H., Cochran, R.C., Titgemeyer, E.C., Vanzant, E.S., Abdelgadir, I. \& St-Jean, G., 1996. Effect of increasing degradable intake protein on intake and digestion of low-quality, tallgrass-prairie forage by beef cows. J. Anim. Sci. 74, 2473-2481.

Kovacs, P., Südekum, K.H. \& Stangassinger, M., 1998. Effects of intake of a mixed diet and time post-feeding on amount and fibre composition of ruminal and faecal particles and on digesta passage from the reticulorumen of steers. Anim. Feed Sci. Technol. 71 (3), 325-340.

Krizsan, S.J., Ahvenjärvi, S. \& Huhtanen, P., 2010. A meta-analysis of passage rate estimated by rumen evacuation with cattle and evaluation of passage rate prediction models. J. Dairy Sci. 93 (12), 5890-5901.

Larsen, M., Lund, P., Weisbjerg, M.R. \& Hvelplund, T., 2009. Digestion site of starch from cereals and legumes in lactating dairy cows. Anim. Feed Sci. Technol. 153 (3), 236-248.

Lechner, I., Barboza, P., Collins, W., Günther, D., Hattendorf, B., Hummel, J. \& Clauss, M., 2009. No 'bypass' in adult ruminants: Passage of fluid ingested vs. fluid inserted into the rumen in fistulated muskoxen, reindeer and moose. Comp. Biochem. Physiol. Part A Mol. Integr. Physiol. 154 (1), 151-156.

Lechner, I., Barboza, P., Collins, W., Fritz, J., Günther, D., Hattendorf, B. \& Clauss, M., 2010. Differential passage of fluids and different-sized particles in fistulated oxen, muskoxen, reindeer and moose: Rumen particle size discrimination is independent from contents stratification. Comp. Biochem. Physiol. Part A Mol. Integr. Physiol. 155 (2), 211-222.

Lechner-Doll, M., Rutagwenda, T., Schwartz, H.J., Schultka, W. \& Von Engelhardt, W., 1990. Seasonal changes of ingesta mean retention time and forestomach fluid volume in indigenous camels, cattle, sheep and goats grazing a thornbush savannah pasture in Kenya. J. Agric. Sci. 115 (3), 409-420.

Lechner-Doll, M., Kaske, M. \& Von Engelhardt, W., 1991. Factors affecting the mean retention time of particles in the forestomach of ruminants and camelids. In: Physiological aspects of digestion and metabolism in ruminants. Eds: Tsuda, T., Sasaki, Y. \& Kwashima, R., Academic, San Diego. pp. 455-488.

Ledoux, D.R., Williams, J.E., Stroud, T.E., Garner, G.B. \& Paterson, J.A., 1985. Influence of forage level on passage rate, digestibility and performance of cattle. J. Anim. Sci. 61 (6), 1559-1566.

Leite, R.F., Krizsan, S.J., Figueiredo, F.O., Carvalho, V.B., Teixeira, I.A. \& Huhtanen, P., 2015. Contribution of different segments of the gastrointestinal tract to digestion in growing Saanen goats. J. Anim. Sci. 93 (4), 1802-1814.

Lewis, R.M., Macfarlane, J.M., Simm, G. \& Emmans, G.C., 2004. Effects of food quality on growth and carcass composition in lambs of two breeds and their cross. Anim. Sci. 78 (3), 355-367.

Lewis, R.M. \& Emmans, G.C., 2010. Feed intake of sheep as affected by body weight, breed, sex, and feed composition. J. Anim. Sci. 88 (2), 467-480.

Lock, A.L. \& Garnsworthy, P.C., 2003. Seasonal variation in milk conjugated linoleic acid and $\Delta 9$ desaturase activity in dairy cows. Livest. Prod. Sci. 79 (1), 47-59.

Lopez, S., Hovell, F.D.D., Dijkstra, J. \& France, J., 2003. Effects of volatile fatty acid supply on their absorption and on water kinetics in the rumen of sheep sustained by intragastric infusion. J. Anim. Sci. 81 (10), 2609-2616.

Mazzenga, A., Gianesella, M., Brscic, M. \& Cozzi, G., 2009. Feeding behaviour, diet digestibility, rumen fluid and metabolic parameters of beef cattle fed total mixed rations with a stepped substitution of wheat straw with maize silage. Livest. Sci. 122 (1), 16-23. 
McCollum, F. \& Galyean, M., 1985. Influence of cottonseed meal supplementation on voluntary intake, rumen fermentation and rate of passage of prairie hay in beef steers. J. Agric. Sci. 60 (2), 570-577.

Merchen, N., Firkins, J. \& Berger, L., 1986. Effect of intake and forage level on ruminal turnover rates, bacterial protein synthesis and duodenal amino acid flows in sheep. J. Anim. Sci. 62 (1), 216-225.

Molina-Alcaide, E., Garcia, A.M. \& Aguilera, J.F., 2000. A comparative study of nutrient digestibility, kinetics of degradation and passage and rumen fermentation pattern in goats and sheep offered good quality diets. Livest. Prod. Sci. 64, 215-223.

Moolchand, M., Wang, J., Gui, H. \& Shen, Z., 2013. Ruminal butyrate infusion increased papillae size and digesta weight but did not change liquid flow rate in the rumen of goats. J. Anim. Plant Sci. 23, 1516-1521.

Moore, J., Poore, M. \& Swingle, R., 1990. Influence of roughage source on kinetics of digestion and passage and on calculated extents of ruminal digestion in beef steers fed 65\% concentrate diets. J. Anim. Sci. 68 (10), 3412-3420.

Mulligan, F.J., Quirke, J., Rath, M., Caffrey, P.J. \& O'Mara, F.P., 2002. Intake, digestibility, milk production and kinetics of digestion and passage for diets based on maize or grass silage fed to late lactation dairy cows. Livest. Prod. Sci. 74 (2), 113-124.

Ndlovu, L.R. \& Buchanan-Smith, J.G., 1985. Utilization of poor quality roughages by sheep: effects of alfalfa supplementation on ruminal parameters, fiber digestion and rate of passage from the rumen. Can. J. Anim. Sci. 65, 693-703.

Nsahlai, I.V., Bryant, M.J. \& Umunna, N.N., 1999. Utilization of barley straw by steers: effects of replacing urea with protein, source of protein and quantity of rumen degradable nitrogen on straw degradation, liquid and particle passage rates and intake. J. Appl. Anim. Res. 16 (2), 129-146.

Nsahlai, I.V. \& Apaloo, J., 2007. On the suitability of the Illius and Gordon's model for simulating the intake and digestibility of roughage diets by ruminants. S. Afr. J. Anim. Sci. 37 (4), 275-289.

Okeke, G., Buchanan-Smith, J. \& Grovum, W., 1983. Effects of buffers on ruminal rate of passage and degradation of soybean meal in steers. J. Anim. Sci. 56 (6), 1393-1399.

Okine, E.K., Mathison, G.W., Kaske, M., Kennelly, J.J. \& Christopherson, R.J., 1998. Current understanding of the role of the reticulum and reticulo-omasal orifice in the control of digeta passage from the ruminoreticulum of sheep and cattle. Can. J. Anim. Sci. 78 (1), 15-21.

Oshita, T., Sudo, K., Nonaka, K., Kume, S. \& Ochiai, K., 2008. The effect of feed regimen on chewing time, digesta passage rate and particle size distribution in Holstein non-lactating cows fed pasture ad libitum. Livest. Sci. 113, 243-250.

Panjaitan, T., Quigley, S.P., McLennan, S.R., Swain, T. \& Poppi, D.P., 2010. Intake, retention time in the rumen and microbial protein production of Bos indicus steers consuming grasses varying in crude protein content. Anim. Prod. Sci. 50 (6), 444-448.

Pond, K.R., Ellis, W.C., Matis, J.H. \& Deswysen, A.G., 1989. Passage of chromium-mordanted and rare earth-labelled fiber: time of dosing kinetics. J. Anim. Sci. 67 (4), 1020-1028.

Poppi, D.P., Norton, B.W., Minson, J.D. \& Hendrickson, R.W., 1980. The validity of the critical size theory for particles leaving the rumen. J. Agric. Sci. 94 (2), 275-280.

Rankins Jr, D.L. \& Bransby, D.I., 1995. Performance, dry matter intake, digesta kinetics, and ruminal fermentation of steers grazing Sorghum halepense at three stocking rates. Trop. Grassl. 29, 102-110.

Raynal-Ljutovac, K., Lagriffoul, G., Paccard, P., Guillet, I. \& Chilliard, Y., 2008. Composition of goat and sheep milk products: An update. Small Ruminant Res. 79 (1), 57-72.

Repository of Experimental Data \& Intelligent Models (REDIM), 18 October 2016. Retrieved from http://www.redim.org.za.

Robles, A.Y., Belyea, R.L. \& Martz, F.A., 1981. Intake, digestibility, ruminal characteristics and rate of passage of alfalfa diets fed to sheep. J. Anim. Sci. 53 (3), 774-779.

SAS, 2011. SAS ${ }^{\circledR}$ 9.3 Software (2nd ed.). SAS Institute Inc., Raleigh, North Carolina, USA.

Sauvant, D., Baumont, R. \& Faverdin, P., 1996. Development of a mechanistic model of intake and chewing activities of sheep. J. Anim. Sci. 74 (11), 2785-2802.

Sauvant, D., Schmidely, P., Daudin, J.J. \& St-Pierre, N.R., 2008. Meta-Analyses of experimental data in animal nutrition. Animal 2 (8), 1203-1214.

Schelling, G.T., 1984. Monensin mode of action in the rumen. J. Anim. Sci. 58 (6), 1518-1527.

Schlecht, E., Richter, H., Fernández-Rivera, S. \& Becker, K., 2007. Gastrointestinal passage of Sahelian roughages in cattle, sheep and goats, and implications for livestock-mediated nutrient transfers. Anim. Feed Sci. Technol. 137 (1), 93-114.

Schoeman, S.J., 1996. Characterisation of beef cattle breeds by virtue of their performances in the National Beef Cattle Performance and Progeny Testing Scheme. S. Afr. J. Anim. Sci. 26 (1), 15-19.

Seo, S., Tedeschi, L.O, Lanzas, C., Schwab, C. \& Fox, D., 2006. Development and evaluation of empirical equations to predict feed passage rate in cattle. Anim. Feed Sci. Technol. 128 (1), 67-83.

Seo, S., Lanzas, C., Tedeschi, L.O. \& Fox, D.G., 2007. Development of a mechanistic model to represent the dynamics of liquid flow out of the rumen and to predict the rate of passage of liquid in dairy cattle. J. Dairy Sci. 90 (2), 840 855.

Seo, S., Lanzas, C., Tedeschi, L.O., Pell, A.N. \& Fox, D.G., 2009. Development of a mechanistic model to represent the dynamics of particle flow out of the rumen and to predict rate of passage of forage particles in dairy cattle. J. Dairy Sci. 92 (8), 3981-4000.

Shem, M.N., Ørskov, E.R. \& Kimambo, A.E., 1995. Prediction of voluntary dry-matter intake, digestible dry-matter intake and growth rate of cattle from the degradation characteristics of tropical foods. Anim. Sci. 60 (1), 65-74. 
Silanikove, N., Tagari, H. \& Shkolnik, A., 1993. Comparison of rate of passage, fermentation rate and efficiency of digestion of high fiber diet in desert Bedouin goats compared to Swiss Saanen goats. Small Ruminant Res. 12 (1), 45-60.

Silanikove, N., Gilboa, N. \& Nitsan, Z., 2001. Effect of polyethylene glycol on rumen volume and retention time of liquid and particulate matter along the digestive tract in goats fed tannin-rich carob leaves. Small Ruminant Res. 40 (1), 95-99.

Stanton, T.L. \& LeValley, S., 2014. Feed composition for cattle and sheep livestock series management. Livestock series management, Fact sheet no. 1.615. Colorado State University extension, Fort Collins, Colorado, USA. http://extension.colostate.edu/docs/pubs/livestk/01615.pdf.

St-Pierre, N.R., 2003. Reassessment of biases in predicted nitrogen flows to the duodenum by NRC 2001. J. Dairy Sci. 86 (1), 344-350.

St-Pierre, N., 2007. Meta-analyses of experimental data in the animal sciences. Rev. Bras. Zootec. 343-358.

Tafaj, M., Steingass, H. \& Drochner, W., 2001. Influence of hay particle size at different concentrate and feeding levels on digestive processes and feed intake in ruminants. 2. Passage, digestibility and feed intake. Arch. Anim. Nutr. $54(3), 243-259$.

Varga, G.A. \& Prigge, E., 1982. Influence of forage species and level of intake on ruminal turnover rates. J. Anim. Sci. 55 (6), 1498-1504.

Varga, G.A. \& Harpster, H.W., 1995. Gut size and rate of passage. In: Intake by Feedlot Cattle Symposium 95. Oklahoma State University, Stillwater, Oklahoma, USA. 85-96.

Warren, W., Martz, F., Asay, K., Hilderbrand, E., Payne, C. \& Vogt, J., 1974. Digestibility and rate of passage by steers fed tall fescue, alfalfa and orchardgrass hay in $18^{\circ} \mathrm{C}$ and $32^{\circ} \mathrm{C}$ ambient temperatures. J. Anim. Sci. 39 (1), 93-96.

Wund, M. \& Myers, P., 2005. Mammalia (online). Animal Diversity Web. Accessed 13 June 2016 at http://animaldiversity.org/accounts/Mammalia/.

Yayota, M., Karashima, J., Kouketsu, T., Nakano, M. \& Ohtani, S., 2009. Seasonal changes in the digestion and passage rates of fresh dwarf bamboo (Pleioblastus argenteostriatus f. glaber) in sheep. Anim. Feed Sci. Technol. 149, 89101. 